\title{
Cytochrome P450 1A1 (CYP1A1) polymorphisms and breast cancer risk in Korean women
}

\author{
Aesun Shin ${ }^{1,2}$, Daehee Kang ${ }^{1}$, \\ Ji-Yeob Choi ${ }^{1,3}$, Kyoung-Mu Lee ${ }^{1,4}$, \\ Sue Kyung Park ${ }^{1}$, Dong-Young Noh ${ }^{5}$, \\ Sei-Hyun $\mathrm{Ahn}^{6}$ and Keun-Young Yoo ${ }^{1,7,8}$ \\ ${ }^{1}$ Department of Preventive Medicine \\ Seoul National University College of Medicine \\ Seoul 110-799, Korea \\ ${ }^{2}$ Research Institute for National Cancer Control and Evaluation \\ National Cancer Center \\ Goyang 410-769, Korea \\ ${ }^{3}$ Department of Epidemiology, Roswell Park Cancer Institute \\ Buffalo, NY, USA \\ ${ }^{4}$ Division of Cancer Epidemiology and Genetics \\ National Cancer Institute, NIH, DHHS \\ Bethesda, MD, USA \\ ${ }^{5}$ Department of Surgery \\ Seoul National University College of Medicine \\ Seoul 110-799, Korea \\ ${ }^{6}$ Department of Surgery \\ Ulsan University College of Medicine \\ Seoul 138-736, Korea \\ ${ }^{7}$ National Cancer Center \\ Goyang 410-769, Korea \\ ${ }^{8}$ Corresponding author: Tel, 82-2-740-8324; \\ Fax, 82-2-747-4830; E-mail, kyyoo@plaza.snu.ac.kr
}

Accepted 4 April 2007

Abbreviations: CYP1A1, cytochrome P450 1A1; BMl, body mass index; $\mathrm{OR}$, odds ratio

\begin{abstract}
Cytochrome P450 1A1 (CYP1A1) is involved in the 2hydroxylation of estrogen, the hormone that plays a critical role in the etiology of breast carcinoma. We evaluated the associations between two CYP1A1 polymorphisms [Mspl (rs4646903); lle462Val (rs1048943)] and breast cancer in a multicenter case-control study of 513 breast cancer cases and 447 controls in Korea. Women carrying the T allele of the CYP1A1 Mspl polymorphism were found to have a 1.72 -fold $(95 \% \mathrm{Cl}$ 1.11-2.68) greater risk of developing breast cancer. No association was found between any CYP1A1 Ile462Val polymorphism and breast cancer. Haplotype analysis of the two loci showed that the CA
\end{abstract}

haplotype was associated with the lowest risk of breast cancer, and CA/CA diplotypes were associated with a lower risk of breast cancer $[O R=0.28$ (0.13-0.61)] than others/others diplotypes. Moreover, this reduced risk was more pronounced among women with a lower body mass index (BMI) $[O R=0.18$ (0.06-0.58)] or with a shorter lifetime exposure to estrogen $[O R=0.23(0.07-0.81)]$. The results obtained suggest that the CYP1A1 Mspl polymorphisms could affect susceptibility to breast cancer.

Keywords: Asian continental ancestry group; breast neoplasms; cytochrome P450 CYP1A1; Korea; polymorphism, genetic

\section{Introduction}

Genes involved in estrogen metabolism are prime targets of breast cancer etiological studies, because estrogen and its metabolites play critical roles in breast cancer initiation and promotion (Service, 1998; Zhu and Conney, 1998). Cytochrome P450 $1 \mathrm{~A} 1$ (CYP1A1) is involved in the conversion of estrone $\left(E_{1}\right)$ and estradiol $\left(E_{2}\right)$ to 2-hydroxyestradiol (2-OHE 1 ) (Cavalieri et al., 2001). CYP1A1 also has aryl hydrocarbon hydroxylase activity which is responsible for metabolizing polycyclic aromatic hydrocarbons (PAH) to aryl epoxides (Law, 1990).

The CYP1A1 lle462 Val polymorphism in exon 7 and the $T 6235 \mathrm{C}$ polymorphism on the $3^{\prime}$ non-coding region (Mspl) have been intensively studied in relation to breast cancer risk (Ambrosone et al., 1995; Taioli et al., 1995; Bailey et al., 1998; Ishibe et al., 1998; Huang et al., 1999; Basham et al., 2001; Krajinovic et al., 2001; da Fonte de Amorim et al., 2002; Laden et al., 2002; Miyoshi and Noguchi, 2003; Hefler et al., 2004; Li et al., 2004; Boyapati et al., 2005; Masson et al., 2005). The Val allele of the Ile462 Val polymorphism was found to be related with increased CYP1A1 gene inducibility (Cosma et al., 1993b; Crofts et al., 1994), and the Mspl polymorphic site was observed to have an effect on gene inducibility in subjects with variant alleles when combined with the lle462 Val polymorphism (Crofts et al., 1994). In this study, we evaluated the potential association between two polymorphisms of the CYP1A1 gene and breast cancer risk in Korean women. 


\section{Materials and Methods}

\section{Study subjects and data collection}

Breast cancer patients and controls were selected from three teaching hospitals in Seoul (Seoul National University Hospital, Borame Hospital, and the Asan Medical Center) between 1995 and 2001. Histologically confirmed incident breast cancer patients who agreed to participate in this study were potential cases, and patients that admitted or who visited the Department of General Surgery in the same hospitals with no previous or present cancer history were recruited as controls. Participants with a history of amenorrhea or oophorectomy were excluded from both groups during data analysis. Informed consents were obtained at the time of blood sampling, and information on demographic characteristics, education, marital status, reproductive history, family history of illness including cancer, smoking, alcohol drinking, and food consumption frequencies was obtained using a structured questionnaire administered by trained interviewers. In the present, 513 breast cancer patients and 447 controls were included.

\section{Genotyping}

DNA was extracted using standard methods from blood drawn into $10 \mathrm{ml}$ heparinized tubes and stored at $-20^{\circ} \mathrm{C}$ until use. Polymorphisms of CYP1A1 were determined using single base extension assays (SnapShot assays). PCR products were obtained using $500 \mathrm{nM}$ oligonucleotide primers (Mspl: (F) 5'-GCTTGCATGCTTGCATAAGA-3', (R) 5'-TAATCCCAGCACTTTGGGAG-3'; codon 462: (F) 5'-GGTCAACCCATCTGAGTTCCTAC-3', (R) 5'-TCATGTCCACCTTCACGC-3') in a total volume of $20 \mu \mathrm{l}$ of reaction mixture. The $\mathrm{PCR}$ amplification profile consisted of an initial denaturation at $95^{\circ} \mathrm{C}$ for $5 \mathrm{~min}$, followed by 35 cycles of $30 \mathrm{~s}$ at $94^{\circ} \mathrm{C}, 60 \mathrm{~s}$ at $54^{\circ} \mathrm{C}$ $\left(58^{\circ} \mathrm{C}\right.$ for $\left.\mathrm{Mspl}\right)$ and $120 \mathrm{~s}$ at $72^{\circ} \mathrm{C}$.

Primer extension reaction was performed by combining $1 \mu$ of exonuclease I and alkaline phosphatase treated PCR product with a $5 \mu \mathrm{l}$ SNaPshot kit (which included DNA polymerase, fluorescently labeled ddNTPs, and control primers), $0.15 \mathrm{pmol}$ extension primer (Mspl: 5'-TTTCACTGTAACCTCCACCTCC-3'; codon 462: 5'-CAAGCGGAAGTGTATCGGTGAGACC-3') and $3 \mu$ water. The reaction mixture was incubated for $2 \mathrm{~min}$ at $94^{\circ} \mathrm{C}$ and then subjected to 25 amplification cycles $\left(5 \mathrm{~s}\right.$ at $95^{\circ} \mathrm{C}, 5 \mathrm{~s}$ at $50^{\circ} \mathrm{C}$, and $5 \mathrm{~s}$ at $60^{\circ} \mathrm{C}$ ). Aliquots of $1 \mu$ of single base extension product and $9 \mu \mathrm{Hi}$-Di formamide were combined in a 96-well 3100 optical microamp plate, and then loaded into a 3100 DNA sequencer (Applied Biosystems, Foster City, CA). Electropho- resis data were processed using Genescan Analysis version 3.7 (Applied Biosystems). Finally, genotyping was successfully performed for 493 cases and 437 controls for the Ile $462 \mathrm{Val}$ polymorphism and for 380 cases and 286 controls for the Mspl polymorphism.

\section{Statistical analysis}

Odds ratios and $95 \%$ confidential intervals were estimated using unconditional logistic regression models adjusted for age, a family history of breast cancer, and lifetime exposure to estrogen. Haplotypes for CYP1A1 were estimated using the Bayesian method with PHASE version 2.1 (Stephens et al., 2001). Subjects who had missing data with at least one polymorphism were excluded from the haplotype analysis. The Chi-square test was used for comparing the haplotype frequencies of cases and controls. Diplotypes were categorized as others/others, others/CA, and CA/CA, because the $\mathrm{CA}$ haplotype was associated with the lowest risk of breast cancer.

Table 1. Characteristics of breast cancer cases and controls.

\begin{tabular}{cccc}
\hline $\begin{array}{c}\text { Participants } \\
\text { characteristics }\end{array}$ & $\begin{array}{c}\text { Cases (\%) } \\
(n=513)\end{array}$ & $\begin{array}{c}\text { Controls (\%) } \\
(n=447)\end{array}$ & OR $(95 \% \mathrm{Cl})^{\mathrm{a}}$ \\
\hline Age (years) & & & \\
-39 & $102(20.7)$ & $146(33.4)$ & 1.0 \\
$40-49$ & $223(45.2)$ & $121(27.7)$ & $2.20(1.44-3.38)$ \\
$50-59$ & $100(20.3)$ & $93(21.3)$ & $1.14(0.68-1.90)$ \\
$60-$ & $68(13.8)$ & $77(17.6)$ & $0.98(0.58-1.65)$
\end{tabular}

Family history of breast cancer in first and second degree relatives

$\begin{array}{lccl}\text { No } & 475(92.7) & 423(96.8) & 1.0 \\ \text { Yes } & 36(7.3) & 14(3.2) & 2.36(1.26-4.41)\end{array}$

Total lifetime estrogen exposure (years)

$\begin{array}{llll}<27 \text { years } & 176(34.5) & 203(46.3) & 1.0 \\ \geq 27 \text { years } & 334(65.5) & 235(53.7) & 1.35(0.91-1.99)\end{array}$

Body mass index (BMI, $\mathrm{kg} / \mathrm{m}^{2}$ )

$\begin{array}{llll}<22.77 & 245(47.8) & 233(52.1) & 1.0 \\ \geq 22.77 & 268(52.2) & 214(47.9) & 1.10(0.84-1.44)\end{array}$

Cigarette smoking

$\begin{array}{llll}400 & & \\ \text { cigarettes } & 458(92.9) & 404(92.5) & 1.0 \\ \text { /lifetime } & & & \\ \begin{array}{l}400 \\ \text { cigarettes }\end{array} & 35(7.1) & 33(7.5) & 0.94(0.57-1.57) \\ \\ \begin{array}{l}\text { /lifetime } \\ \text { lime }\end{array}\end{array}$

adjusted for age, total lifetime exposure to estrogen, and a family history of breast cancer. 
Table 2. Association between the CYP1A1 lle462Val and Mspl polymorphisms and breast cancer risk.

\begin{tabular}{|c|c|c|c|c|}
\hline $\begin{array}{c}\text { CYP1A1 } \\
\text { genotypes }\end{array}$ & Cases (\%) & Controls (\%) & OR $(95 \% \mathrm{Cl})^{\mathrm{a}}$ & $P$ for trend \\
\hline \multicolumn{5}{|l|}{ All participants } \\
\hline Mspl (rs4646903) & $(n=380)$ & $(n=286)$ & & \\
\hline $\mathrm{CC}$ & $60(15.8)$ & 73 (25.5) & 1.0 & \\
\hline CT & $173(45.5)$ & $118(41.3)$ & $1.80(1.17-2.75)$ & \\
\hline $\mathrm{TT}$ & $147(38.7)$ & $95(33.2)$ & $1.72(1.11-2.68)$ & 0.03 \\
\hline $\mathrm{CT}+\mathrm{TT}$ & $320(61.1)$ & $213(67.4)$ & $1.76(1.19-2.61)$ & \\
\hline Ile462Val (rs1048943) & $(n=493)$ & $(n=437)$ & & \\
\hline Ile/lle & $252(51.1)$ & $232(53.1)$ & 1.0 & \\
\hline Ile/Val & $213(43.2)$ & $175(40.0)$ & $1.17(0.89-1.54)$ & \\
\hline Val/Val & $28(5.7)$ & $30(6.9)$ & $0.98(0.56-1.71)$ & 0.51 \\
\hline Ile/Val + Val/Val & 241 (48.9) & 205 (46.9) & $1.14(0.88-1.49)$ & \\
\hline Number of risk alleles ${ }^{b}$ & $(n=360)$ & $(n=276)$ & & \\
\hline 0 & $95(26.4)$ & $105(38.0)$ & 1.0 & \\
\hline $1-3$ & $265(73.6)$ & $171(62.0)$ & $1.39(1.04-1.85)$ & \\
\hline
\end{tabular}

${ }^{a}$ adjusted age, total lifetime estrogen exposure, and family history of breast cancer. ${ }^{b}$ Val allele for Ile462Val and T allele for Mspl.

\section{Results}

The demographic characteristics and the known risk factors of breast cancer of study subjects are presented in Table 1. Significant differences between cases and controls were found for age distribution and a family history of breast cancer among first and second degree relatives.

The distributions of the CYP1A1 gene polymorphisms are presented in Table 2. The genotype frequencies of the Ile $462 \mathrm{Val}$ polymorphisms in controls did not deviate from Hardy-Weinberg equilibrium, however, the genotype frequencies of the Mspl polymorphisms in controls did deviate from Hardy-Weinberg equilibrium $(P=0.02)$. Overall, no association was found between the lle462 Val polymorphism and breast cancer risk. However, women with the T allele of the Mspl polymorphism showed a 1.76 -fold higher risk of breast cancer $(95 \% \mathrm{Cl}=$ 1.19-2.61). When the risk alleles of the two polymorphisms combined (Val allele for lle462Val and T allele for Mspl), women who had at least one risk allele showed a 1.4-fold increase in risk for breast cancer compared to women who did not have risk allele.

Table 3 presents the distributions of the CYP1A1 gene haplotypes in breast cancer cases and controls. Two alleles were found to be in strong linkage disequilibrium with each other $\left(D^{\prime}=0.77, P\right.$ $<0.001$ ) with 1,344 base pairs apart. Four haplotypes were estimated from the genotype data, and haplotype frequencies differed for cases and
Table 3. Distributions of CYP1A1 haplotypes in breast cancer cases and controls.

\begin{tabular}{ccccc}
\hline Haplotypes $^{\mathrm{a}}$ & $\begin{array}{c}\text { Cases } \\
(\%)\end{array}$ & $\begin{array}{c}\text { Controls } \\
(\%)\end{array}$ & $\begin{array}{c}\text { aOR } \\
(95 \% \mathrm{Cl})^{\mathrm{b}}\end{array}$ & $\begin{array}{c}P \\
\left(\chi^{2} \text { test }\right)\end{array}$ \\
\hline TA & $418(58.1)$ & $273(49.5)$ & 1.0 & \\
CG & $170(23.6)$ & $132(23.9)$ & $0.91(0.69-1.21)$ & \\
CA & $105(14.6)$ & $127(23.0)$ & $0.59(0.43-0.80)$ & \\
TG & $27(3.7)$ & $20(3.6)$ & $0.82(0.44-1.52)$ & $<0.001$ \\
\hline
\end{tabular}

${ }^{a}$ Composed of two polymorphic sites: Mspl T $>$ C and lle462Val A $>$ G. ${ }^{\mathrm{b}}$ Adjusted for age, total lifetime exposure to estrogen, and a family history of breast cancer.

controls $\left(P_{\text {Global test }}<0.001\right)$. The frequency of the CA haplotype was lower in breast cancer cases than in controls. Compared to others/others diplotypes, others/CA diplotypes showed a reduced risk of breast cancer [OR $=0.72(0.50-1.04)$ ] (Table 4), and the $\mathrm{CA} / \mathrm{CA}$ diplotype showed a further reduction in risk [OR $=0.28(0.13-0.61)]$, and this trend toward a reduced risk was significant $(P<0.001)$.

Table 5 presents the results of analyses stratified by hormone-related factors. Body mass index, age at menarche, and total estrogen exposure were divided about median values. The reduced risk of the CA/CA diplotype was pronounced for those with a low BMI $\left(<22.77 \mathrm{~kg} / \mathrm{m}^{2}\right)$ [OR $\left.=0.18(0.06-0.58)\right]$, a short total estrogen exposure $(<27$ years) [OR $=$ $0.23(0.07-0.81)]$, and for premenopausal women 
Table 4. CYP1A1 diplotypes and breast cancer risk.

\begin{tabular}{lcclc}
\hline Diplotype $^{\mathrm{a}}$ & Cases $(\%)$ & Controls $(\%)$ & OR $(95 \% \mathrm{Cl})^{\mathrm{b}}$ & $P$ for trend \\
\hline Others/others & $265(73.6)$ & $171(61.9)$ & 1.0 & \\
Others/CA & $85(23.6)$ & $83(30.1)$ & $0.72(0.50-1.04)$ & $<0.001$ \\
CA/CA & $10(2.8)$ & $22(8.0)$ & $0.28(0.13-0.61)$ & \\
\hline
\end{tabular}

${ }^{a}$ Composed of two polymorphic sites: Mspl T $>\mathrm{C}$ and lle462Val A $>\mathrm{G}$. ${ }^{\mathrm{b}}$ Adjusted for age, total lifetime exposure to estrogen, and a family history of breast cancer.

Table 5. Association of CYP1A1 diplotypes with breast cancer risk by selected breast cancer risk factors.

\begin{tabular}{|c|c|c|c|c|c|c|}
\hline & \multicolumn{2}{|c|}{ Others/others } & \multicolumn{2}{|c|}{ Others/CA } & \multicolumn{2}{|r|}{$\mathrm{CA} / \mathrm{CA}$} \\
\hline & $\begin{array}{l}\text { Cases/ } \\
\text { controls }\end{array}$ & $O R^{b}$ & $\begin{array}{c}\text { Cases/ } \\
\text { controls }\end{array}$ & $\mathrm{OR}(95 \% \mathrm{Cl})^{\mathrm{b}}$ & $\begin{array}{l}\text { Cases/ } \\
\text { controls }\end{array}$ & OR $(95 \% \mathrm{Cl})^{\mathrm{b}}$ \\
\hline \multicolumn{7}{|c|}{ Body mass index (BMI, $\mathrm{kg} / \mathrm{m}^{2}$ ) } \\
\hline$<22.77$ & $129 / 83$ & 1.0 & $43 / 43$ & $0.73(0.43-1.24)$ & $5 / 11$ & $0.18(0.06-0.58)$ \\
\hline$\geq 22.77$ & $136 / 88$ & 1.0 & $42 / 40$ & $0.71(0.42-1.19)$ & $5 / 11$ & $0.35(0.12-1.05)$ \\
\hline \multicolumn{7}{|l|}{ Menopausal status } \\
\hline Premenopausal & $171 / 98$ & 1.0 & $54 / 46$ & $0.76(0.47-1.23)$ & $6 / 15$ & $0.23(0.08-0.62)$ \\
\hline Postmenopausal & $94 / 72$ & 1.0 & $31 / 36$ & $0.66(0.37-1.18)$ & $4 / 7$ & $0.43(0.12-1.56)$ \\
\hline \multicolumn{7}{|c|}{ Lifetime estrogen exposure (years) } \\
\hline$<27$ & $98 / 74$ & 1.0 & $30 / 39$ & $0.72(0.40-1.30)$ & $4 / 12$ & $0.23(0.07-0.81)$ \\
\hline$\geq 27$ & $167 / 97$ & 1.0 & $55 / 44$ & $0.76(0.47-1.22)$ & $6 / 10$ & $0.33(0.12-0.96)$ \\
\hline
\end{tabular}

${ }^{a}$ Composed of two polymorphic sites: Mspl T $>\mathrm{C}$ and lle462Val A $>\mathrm{G}$. ${ }^{\mathrm{b}}$ adjusted for age, total lifetime exposure to estrogen, and a family history of breast cancer

$[\mathrm{OR}=0.23(0.08-0.62)]$

\section{Discussion}

Our results suggest that CYP1A1 Mspl polymorphisms may affect breast cancer susceptibility in Korean women, and haplotype analysis may provide more information on the risk assessment.

Several studies have been conducted on the association between polymorphisms of the CYP1A1 gene and breast cancer risk (Ambrosone et al., 1995; Taioli et al., 1995; Bailey et al., 1998; Ishibe et al., 1998; Huang et al., 1999; Basham et al., 2001; Krajinovic et al., 2001; da Fonte de Amorim et al., 2002; Laden et al., 2002; Miyoshi and Noguchi, 2003; Hefler et al., 2004; Li et al., 2004; Boyapati et al., 2005; Masson et al., 2005). Overall, the Ile462 Val polymorphism was found to show a null or weak association with breast cancer risk (Masson et al., 2005), whereas 1.36-5.22 fold increases in breast cancer risk were reported in subgroups of smokers or in women with higher serum poly- chlorinated-biphenyls (PCB) levels (Miyoshi and Noguchi, 2003). In our study, the proportion of women who smoked was low (7-7.5\%), which concurs with the prevalence of smoking among Korean women (http://www.nso.go.kr/newnso/s_data/search_ kosis.html), therefore subgroup analysis for smokers did not have sufficient statistical power (data not shown). The $\mathrm{C}$ allele of the $\mathrm{Mspl}$ polymorphism was found to be associated with a significantly higher risk of breast cancer in African-American women (Taioli et al., 1995), in smokers (Ishibe et al., 1998), and in Taiwanese postmenopausal women (Huang et al., 1999), whereas it was found to be associated with a reduced risk in Japanese (Miyoshi and Noguchi, 2003) and Chinese women (Boyapati et al., 2005), which concurs with the findings of the present study, whereas another study performed in the Caucasian and African-American population did not produce a significant result (Bailey et al., 1998). Interestingly, substantial racial differences in variant allele frequencies and risk estimates were observed. Asian and African-American showed higher frequencies of variant allele of $\mathrm{Mspl}$ polymorphisms 
$(22-40 \%)$ than Caucasian women (11-12\%) (Cosma et al., 1993a; Taioli et al., 1995; Ishibe et al., 1998; Huang et al., 1999; Boyapati et al., 2005). Moreover, an opposite association was observed between Mspl polymorphisms and breast cancer risk in Caucasian and African-American women, although the individual associations for either race were not statistically significant (Bailey et al., 1998).

It is known that the Mspl and Ile462 Val polymorphisms are in linkage disequilibrium (Whitlock, 1999). However, no study has used haplotypes to assess breast cancer risk to date. A study in Chinese women used combinations of two polymorphisms and observed a significantly reduced risk of breast cancer in women homozygous for both variant alleles (CC for Mspl and GG for lle462 Val) compared with those homozygous for both wild-type alleles (TT for Mspl and AA for lle462 Val) (Boyapati et al., 2005), which was the same direction with our result regarding $\mathrm{Mspl}$ genotype. Interestingly, risk reduction was prominent among postmenopausal women with a lower waist-to-hip ratio or a lower BMI (Boyapati et al., 2005). However, in the present study, the CA haplotype was associated with the lowest risk of breast cancer.

Our result should be interpreted with caution, since genotype frequency for Mspl among control population was deviated from Hardy-Weinberg equilibrium. There has been one report for genotype frequency of $\mathrm{Mspl}$ polymorphism in Korean population (Hong et al., 1998). Hong et al. (1998) reported a minor allele frequency of 0.3 for $\mathrm{Mspl}$ polymorphism in a control group consisted with 63 subjects. Therefore, the genotype frequency of this polymorphism among Korean population needs to be confirmed in other studies.

In conclusion, our study suggests that the Mspl polymorphisms are associated with breast cancer risk in Korean women. Further large-scales studies on this association are required to confirm the differential effects of the haplotypes of the CYP1A1 gene among races.

\section{Acknowledgement}

This research was supported in part by the 2001 Good Health R\&D Project, Ministry of Health and Welfare, Korea (Grant No. 01-PJ1-PG3-21900-0006).

\section{References}

Ambrosone CB, Freudenheim JL, Graham S, Marshall JR, Vena JE, Brasure JR, Laughlin R, Nemoto T, Michalek AM, Harrington A, et al. Cytochrome P4501A1 and glutathione S-transferase (M1) genetic polymorphisms and postmenopausal breast cancer risk. Cancer Res 1995;55:3483-5
Bailey LR, Roodi N, Verrier CS, Yee CJ, Dupont WD, Parl FF. Breast cancer and CYPIA1, GSTM1, and GSTT1 polymorphisms: evidence of a lack of association in Caucasians and African Americans. Cancer Res 1998;58:65-70

Basham VM, Pharoah PD, Healey CS, Luben RN, Day NE, Easton DF, Ponder BA, Dunning AM. Polymorphisms in CYP1A1 and smoking: no association with breast cancer risk. Carcinogenesis 2001;22:1797-800

Boyapati SM, Shu XO, Gao YT, Cai Q, Jin F, Zheng W. Polymorphisms in CYP1A1 and breast carcinoma risk in a population-based case-control study of Chinese women. Cancer 2005;103:2228-35

Cavalieri EL, Kumar S, Todorovic R, Higginbotham S, Badawi AF, Rogan EG. Imbalance of estrogen homeostasis in kidney and liver of hamsters treated with estradiol: implications for estrogen-induced initiation of renal tumors. Chem Res Toxicol 2001;14:1041-50

Cosma G, Crofts F, Currie D, Wirgin I, Toniolo P, Garte SJ. Racial differences in restriction fragment length polymorphisms and messenger RNA inducibility of the human CYP1A1 gene. Cancer Epidemiol Biomarkers Prev 1993a;2: $53-7$

Cosma G, Crofts F, Taioli E, Toniolo P, Garte S. Relationship between genotype and function of the human CYP1A1 gene. J Toxicol Environ Health 1993b;40:309-16

Crofts F, Taioli E, Trachman J, Cosma GN, Currie D, Toniolo $P$, Garte SJ. Functional significance of different human CYP1A1 genotypes. Carcinogenesis 1994;15:2961-3

da Fonte de Amorim L, Rossini A, Mendonca G, Lotsch P, de Almeida Simão T, de Moura Gallo C, Pinto L. CYP1A1, GSTM1, and GSTT1 polymorphisms and breast cancer risk in Brazilian women. Cancer Lett 2002;181:179-86

Hefler LA, Tempfer CB, Grimm C, Lebrecht A, Ulbrich E, Heinze G, Leodolter S, Schneeberger C, Mueller MW, Muendlein A, Koelbl H. Estrogen-metabolizing gene polymorphisms in the assessment of breast carcinoma risk and fibroadenoma risk in Caucasian women. Cancer 2004;101: 264-9

Hong YS, Chang JH, Kwon OJ, Ham YA, Choi JH. Polymorphism of the CYP1A1 and glutathione-S-transferase genes in Korean lung cancer patients. Exp Mol Med 1998; 30:192-8

http://www.nso.go.kr/newnso/s_data/search_kosis.html

Huang CS, Shen CY, Chang KJ, Hsu SM, Chern HD. Cytochrome $\mathrm{P} 4501 \mathrm{~A} 1$ polymorphism as a susceptibility factor for breast cancer in postmenopausal Chinese women in Taiwan. Br J Cancer 1999;80:1838-43

Ishibe N, Hankinson SE, Colditz GA, Spiegelman D, Willett WC, Speizer FE, Kelsey KT, Hunter DJ. Cigarette smoking, cytochrome $\mathrm{P} 4501 \mathrm{~A} 1$ polymorphisms, and breast cancer risk in the Nurses' Health Study. Cancer Res 1998;58:667-71

Krajinovic M, Ghadirian P, Richer C, Sinnett H, Gandini S, Perret C, Lacroix A, Labuda D, Sinnett D. Genetic susceptibility to breast cancer in French-Canadians: role of carcinogenmetabolizing enzymes and gene-environment interactions. Int J Cancer 2001;92:220-5 
Laden F, Ishibe N, Hankinson SE, Wolff MS, Gertig DM, Hunter DJ, Kelsey KT. Polychlorinated biphenyls, cytochrome P450 $1 \mathrm{~A} 1$, and breast cancer risk in the Nurses' Health Study. Cancer Epidemiol Biomarkers Prev 2002;11:1560-5

Law MR. Genetic predisposition to lung cancer. Br J Cancer 1990;61:195-206

Li Y, Millikan RC, Bell DA, Cui L, Tse CK, Newman B, Conway K. Cigarette smoking, cytochrome P4501A1 polymorphisms, and breast cancer among African-American and white women. Breast Cancer Res 2004;6:R460-73

Masson LF, Sharp L, Cotton SC, Little J. Cytochrome P-450 $1 \mathrm{~A} 1$ gene polymorphisms and risk of breast cancer: A HuGE Review. Am J Epidemiol 2005;161:901-15

Miyoshi Y, Noguchi S. Polymorphisms of estrogen synthesizing and metabolizing genes and breast cancer risk in Japanese women. Biomed Pharmacother 2003;57:471-81
Service RF. New role for estrogen in cancer? Science 1998; 279:1631-3

Stephens M, Smith N, Donnelly P. A new statistical method for haplotype reconstruction from population data. Am J Human Genetics 2001;68:978-89

Taioli E, Trachman J, Chen X, Toniolo P, Garte SJ. A CYP1A1 restriction fragment length polymorphism is associated with breast cancer in African-American women. Cancer Res 1995; $55: 3757-8$

Whitlock JP. Induction of cytochrome P4501A1. Annu Rev Pharmacol Toxicol 1999;39:103-25

Zhu BT, Conney AH. Functional role of estrogen metabolism in target cells: review and perspectives. Carcinogenesis 1998; 19:1-27 